\title{
ACUTE VIRAL BRONCHIOLITIS AS A CAUSE OF PAEDIATRIC ACUTE RESPIRATORY DISTRESS SYNDROME (PARDS)
}

\author{
1,3Marwa Ghazaly , 3Duaa Rafaat , ${ }^{3}$ Naglaa Hassan, , ${ }^{3}$ Nagwa Ali, ${ }^{1,2}$ Simon Nadel \\ 1-Paediatric Intensive Care Unit, St Mary's Hospital, Imperial College Healthcare Trust, London, UK \\ 2-Imperial College London, UK;
}

3- Paediatric Department, Faculty of medicine, Assuit university, Egypt

\section{Background and Aims}

The Paediatric Acute Lung Injury Consensus Conference (PALICC) published paediatric-specific guidelines for the definition, management and research in PARDS. Acute Viral Bronchiolitis (AVB) remains one of the leading causes of admission to PICU. Respiratory Syncytial Virus (RSV) is the most common cause of $A V B$. We wished to evaluate the incidence of PARDS in AVB and identify the risk of RSV as a trigger pathogen for PARDS.

\section{Method}

Retrospective single centre cohort study, including children 0-1 years admitted to PICU at St Mary's Hospital, London with AVB in the years 2015/16, 2016/17 and 2017/18). PALICC criteria were applied to define PARDS. Clinical and demographic data was collected, non-parametric tests were used.

\section{Results}

144 patients with AVB were included, median age $=8$ weeks (IQR 28-180 days), 62\% male, 52\% presented with apnoea, 44\% were premature and 108 met criteria for PARDS or were at risk for PARDS. Of these 108, 45 met PARDS criteria and 63 were "at risk of PARDS". 42\% of the 144 infants had RSV as a single pathogen; $19 \%$ had mixed virology, $17 \%$ also had bacteria isolated.

\section{Conclusion}

AVB is an important cause of PARDS in infants. RSV is associated with a higher risk of PARDS in AVB, RSV is a potentially preventable cause of PARDS.

\begin{tabular}{|l|l|l|l|l|} 
& Odds ratio & $\begin{array}{l}\text { 95\% C.I. for } \\
\text { EXP(B) }\end{array}$ & & $P$-value \\
\hline $\begin{array}{l}\text { RSV } \\
\text { infection }\end{array}$ & 2.388 & 1.002 & 5.691 & .049 \\
\hline age & .999 & .992 & 1.005 & .674 \\
\hline wt & .950 & .654 & 1.382 & .790 \\
\hline Sex (male) & 1.691 & .733 & 3.899 & .218 \\
\hline prematurity & 1.418 & .550 & 3.655 & .470 \\
\hline apnea & 1.112 & .407 & 3.09 & .997 \\
\hline comorbidty & 0.68 & 0.268 & 1.747 & .731 \\
\hline coinfection & .895 & .324 & 2.472 & .830 \\
\hline Noninvasive & 1.105 & .455 & 2.684 & .825 \\
\hline
\end{tabular}

Table1: multivariate analysis to predict risk factors for PARDS development in Infants with AVB.

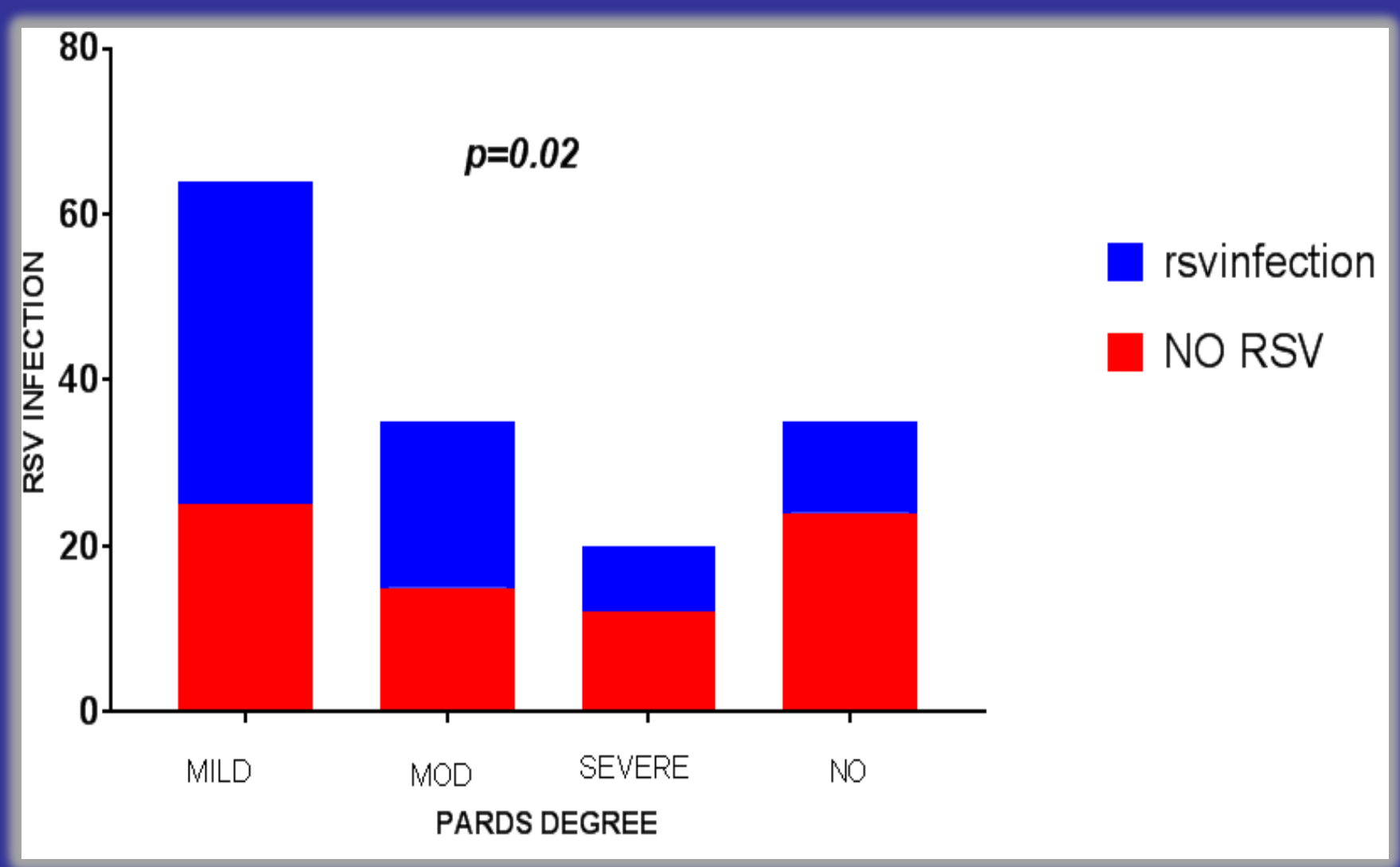

